\title{
KNOWLEDGE OF, AND BEHAVIOR IN RESPONSE TO, COVID-19 PANDEMIC BY PREGNANT NIGERIAN IGBO WOMEN
}

\author{
Joseph Ifeanyi Adinma ${ }^{1}$, Chukwunonso Enechukwu ${ }^{1}$, Anthony Nnedum², Nneoma \\ Adinma-Obiajulu ${ }^{1}$, and Ekene Emeka ${ }^{2}$ \\ ${ }^{1}$ Nnamdi Azikiwe University Teaching Hospital \\ ${ }^{2}$ Nnamdi Azikiwe University
}

June 23, 2021

\begin{abstract}
Background: The Covid-19 pandemic currently represents a foremost global contemporary public health challenge, with alarming death rate. Pregnant women by virtue of reduced immunity may be at increased risk of contracting the disease. Objective: To elicit the knowledge of, and behavior, in response to the covid-19 pandemic among pregnant Nigerian Igbo women. Subjects and methods: Cross-sectional questionnaire-based study of 370 pregnant women from health facilities in Anambra state Nigeria, to elicit information on their knowledge of causes, mode of transmission, availability of vaccines, treatment modalities, and behavioural changes consequent on covid-19. Data obtained was analyzed using SPSS IBM windows version 26 . Result: The modal age, parity and gestational age of the respondents were $25-29$ years (49.2\%); Para 1-4(89.5\%) and <28 weeks (44.1\%) respectively. Majority of the participants had tertiary education (54.1\%) and of modal social class 5 . All (100\%) of the participants knew about covid-19; $91.4 \%$ recognized it was of viral aetiology; and $75.1 \%$ agreed it is an infectious disease. Indicated modes of transmission include air, droplets, faeces, urine, dust, ingested foods, and drinks. Most of the participants recognized the unavailability of drugs (88.6\%) and vaccine (80\%) for covid-19 management. Stated treatment modalities include symptomatic therapy; inhalation of steam from hot water, herbs, and roots; consumption of spices; antimalarial, Antibiotics, Multivitamins therapy; physical exercises; rest; and prayer. Majority of the respondents (67\%) believed that covid-19 had affected their general behavior and most adhered to covid-19 safety measures - wearing of face mask; hand washing; use of hand-sanitizers and social distancing. The most common source of information to participants on covid-19 was electronic media. Conclusion: The knowledge of covid-19 among the respondents was high and their behavior, satisfactory. There is need to maintain the public enlightenment tempo to sustain the good behavior in response to covid-19 amongst pregnant women.
\end{abstract}

\section{Hosted file}

Dr Enechukwu Publication 16 Jan 2021.docx available at https://authorea.com/users/421440/ articles/527475-knowledge-of-and-behavior-in-response-to-covid-19-pandemic-by-pregnantnigerian-igbo-women

\section{Hosted file}

Tables with their titles.docx available at https://authorea.com/users/421440/articles/527475knowledge-of-and-behavior-in-response-to-covid-19-pandemic-by-pregnant-nigerian-igbowomen 